\title{
Enhancing Thai Engineering Students' Complaints and Apologies through Pragmatic Consciousness-Raising Approach (PCR)
}

Uraiwan Rattanapan Noonkong*, Anamai Damnet, Kanjana Charttrakul

Kasetsart University, Kampaeng Saen Campus, Thailand

Corresponding Author: Uraiwan Rattanapan Noonkong, E-mail: talamod_23@hotmail.com

\section{ARTICLE INFO}

\section{Article history}

Received: September 11, 2017

Accepted: November 17, 2017

Published: December 30, 2017

Volume: 8 Issue: 6

Advance access: December 2017

Conflicts of interest: None

Funding: None

\section{Key words:}

Pragmatic Competence,

Complaints,

Apologies,

Appropriateness,

Pragmatic Consciousness-Raising (PCR)

\begin{abstract}
Successful communication requires "Pragmatic Competence" or abilities to use appropriate language in transferring one's needs while maintaining a positive relationship with the interactant (Thomas, 1995; Leech, 1983). This study was an attempt to investigate the pragmatic competence of Thai Engineering students when making complaints and apologies through twelve sessions of a pragmatic consciousness-raising approach (PCR). Perceptions toward the innovative teaching activities were also examined. Both qualitative and quantitative methods were used to collect data from forty-five engineering students $(n=45)$ at a university in Thailand. Pre-test and posttest written discourse completion tests (WDCTs) were administered and a semi-structured interview was conducted. Three native speaker raters scored the performances through WDCTs using assessment criteria from Hudson (2001) and Duan (2008). For data analysis, paired-samples t-test was employed to compare the mean scores of students, while the researcher employed a Grounded Theory's color coding technique (Strauss \& Corbin, 1998) to generate the findings on students' perceptions about the innovative methods implemented. The results revealed significant development of students' pragmalinguistic and sociopragmatic abilities in both complaints and apologies. Furthermore, participants perceived the PCR class to be beneficial in four areas: having more awareness of the impacts of social factors in language use, realizing the favor of indirect strategies, more understanding of nonverbal communication, and provision of motivating class atmosphere. However, some participants concerned about three aspects: inadequate confidence to use expressions learned in class in real communication, insufficient endeavor to develop grammar knowledge, and the test abilities of the roleplay test. The results confirm the teachability of pragmatic and the benefits of PCR in EFL contexts; whereas, students' concern about learning through the approach might be helpful for further teaching practices.
\end{abstract}

This research was supported from graduate scholarship provided by the National Research Council of Thailand (NRCT) as of fiscalyear 2017.

\section{INTRODUCTION}

The educational policies of the Thai government are in line with proposals of ELT experts who maintain the promotion of pragmatic competence in class (McKay, 2002; LoCastro, 1990). The competence includes linguistic competence (pragmalinguistics for and abilities to employ those linguistic resources appropriately or sociolinguistic competence (sociopragmatics for Thomas, 2015 and Leech,1983) in each intercultural communication context (Baker, 2011; Cohen, 2010; Pinya \& Aksornjarung, 2010; Laopongharn \& Sercombe, 2009). However, previous studies revealed that, ELT in Thailand tended to focus exclusively on the mastery of linguistic abilities (Choomtong, 2014; Wongsothorn, Hirunburana, \& Chinnawong, 2006). Similarly, Wichien and Aksornjarung (2011) found both qualitative and quantitative insufficiency of pragmatic information in course books for undergraduate students. This results in the poor English communicative abilities of Thai students (Ngowananchai, 2013).
The situation seemed to be more severe for engineering students as previous studies found that they are likely to have low English proficiency. For example, Panyawong-Ngam, Tangthong, \& Anunvrapong (2015) investigated Thai engineering students' English abilities and found very poor scores on through TOIEC test. The standardized test features communicative situations relating to real-life situations that are relevant to global workplaces (The TOEIC® Tests the Global Standard for Assessing English Proficiency for Business, n.d.). In order to confirm the phenomena, a preliminary investigation with fourteen engineering students who shared similar characteristics to the participants of this study showed their inadequate abilities to use correct refusal expressions and apply appropriate politeness to different interactants. A native speaker rater perceived their use of English as being rude and unacceptable. Thus, it was obvious that engineering students were unsuccessful in conveying their communicative goals. Consequently, it is beneficial to 
develop and examine the pragmatic competence of engineering students in Thailand.

This study employed a pragmatic consciousness-raising approach (PCR) (Ishihara N., 2010, p. 113; Ellis, 1992, p. 223) in developing Thai engineering students' use of English. PCR is proved to be effective in promoting both pragmalinguistic and sociopragmatic competence (Rose K. R., 1994). It associates with explicit teaching, which refers to the efforts to provide learners understanding of a certain language feature and has proved to be beneficial in pragmatic classes (Ishihara \& Cohen, 2010; Rudolph, 2001) and requires the learners' conscious or deliberate attempts to acquire certain language abilities (Dornyei, 2013). This study focused on complaints and apologies because of the difficulties and reluctance speakers may encounter when communicating negative feeling or guilt to others. In addition, these two communicative functions are considered face-threatening as they tend to damage or threaten the face of interactants easily (Brown \& Levinson, 1987).

To develop and investigate Thai engineering students' pragmatic abilities in making complaints and apologies through PCR approach and their perception on the method, the answers to the following research questions were obtained;

1. To what extent do Thai engineering students use linguistic expressions with regard to complaints and apologies through pragmatic consciousness-raising classes?

2. In what ways do students employ complaint and apology strategies to interlocutors with different relative power and distance through pragmatic consciousness-raising classes?

3. How do students perceive learning English through consciousness-raising classes?

\section{LITERATURE REVIEW}

This section outlines the underlying theories, concepts, and previous studies that facilitate the conducting of this study. It includes three areas as follows:

\section{Pragmatic Competence}

Pragmatic refers to interpersonal speech-making which relates to the methods of achieving speakers' or writers' objectives of conveying one' intention and at the same time maintaining close relationship with others (Thomas, 1995; Leech, 1983). According to Cohen (2010, p. 3), pragmatic abilities must be presented through four main channels of communication; listening, reading, speaking, and writing. For example, as a speaker one should transfer the intention to the right interactants with appropriate directness, politeness, and formality (Cohen, 2010, p. 3). Hence, pragmatic competence does not rely exclusively on grammatical abilities; in addition, sociolinguistic knowledge/competence (or sociopragmatics for Thomas, 1995) is crucial (Soler \& Matines-Flor, 2008). To support the notion, previous studies found that regardless of learners' advanced English proficiency; they perform differently from native speakers' pragmatic norms (Bardovi-Harlig, 2001).

\section{Complaints and Apologies}

Complaints refer to the expression of displeasure, disapproval, annoyance, blame, censure, threats, or reprimand which is resulted from offense or violation of social conventions (Trosborg, 1995). Similarly, speech act of apologies associate with expression of sorry and rationale of the offense, and repair for it (Center for Advanced Research on Language Acquisition, 2015). Both are face-threatening acts, which are usually against hearers' expectation about self-image (Yule, 1996). Besides, conveying the speech acts are more complexed as culture of the speakers is usually transferred through their language use (LoCastro, 1945).

Previous literature and comparative studies confirmed variations of complaints (Furukawa, 2006; Shea, 2003; Lee, 1999) and apologies (Cheng, 2013; Sukimoto, 1995) performed by native speakers of English and the nonnative participants in many aspects such as the formulae, strategies choices, realization of impact of contextual factors, as well as pronunciation. The three most complaint strategies by native speakers of English are "Justification," "Problems," and "Repair" (Shea, 2003; Ho, Henry, \& Alkaff, 2012), while "Offer of repair," "Explicit apology," "Account/Explanation" were mostly found in native speakers' apologies (Center for Advanced Research on Language Acquisition, 2015; Cheng, 2013; Sukimoto, 1995; Bergman \& Kasper, 1993). The results were used as baseline data during the innovative phases in this study.

\section{Pragmatic Consciousness-Raising (PCR)}

Schmidt (2010; 2013; 1999) has proposed Noticing Hypothesis with the underlying assumption that language acquisition initiates from attention that requires conscious practices. He maintains that second language acquisition refers to the circumstance in which people learn about the things they pay attention to and do not learn much to those to which they pay little attention (Schmidt, 2010; 1993). According to this framework, pragmatic information such as "forms," "functional meaning," and "relevant contextual features" must be consciously paid attention to for pragmatic learning to occur. After the information is noticed, the input can potentially become intake and may be stored in a long-term memory (Schmidt, 1993)

In line with the Noticing Hypothesis, the consciousness-raising approach (awareness- raising for Ishihara \& Cohen, 2010) is adopted extensively in modern pragmatic classes (Dersiderio, 2011; Ishihara \& Cohen, 2010; Ping, 2010; Narita, 2009; Rose K. R., 1994). The approach associates with an explicit teaching of pragmatic competence, which takes Noticing Hypothesis as an underlying assumption. It is aimed for assisting learners' observation and understanding of the relations between forms and contexts (Ishihara N., 2010 , p. 112) and promoting automatic awareness of pragmatics of English in various communicative situations (Rose K. R., 1994).

The following Diagram 1 illustrates the underlying assumption of consciousness-raising, which integrates the Noticing Hypothesis (Schmidt, 1990; 1993), Ishihara \& Cohen (2010), and Leech's General Pragmatics (1983). 


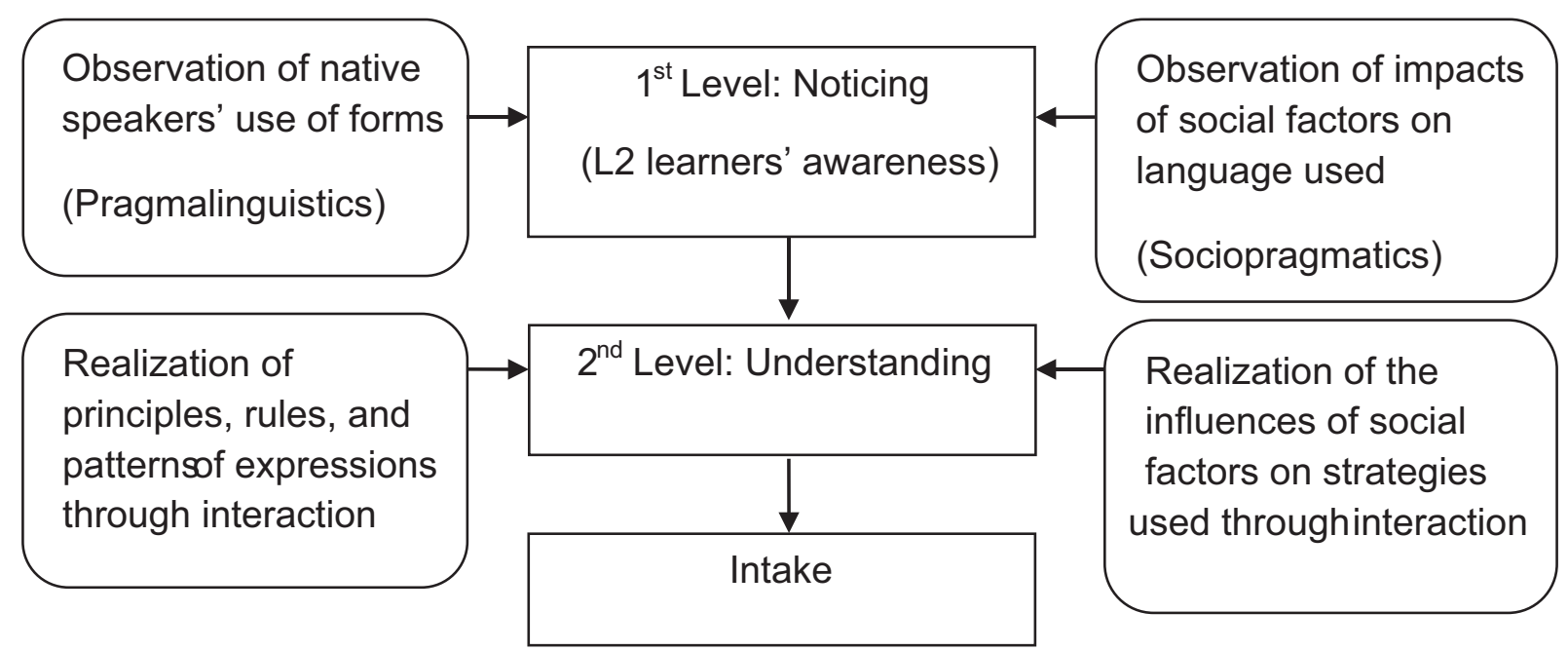

Diagram 1. Pragmatic Consciousness-Raising Model. (Adapted from Schmidt, 2010,1993; Ishihara \& Cohen, 2010, and Leech, 1983)

According to the diagram, teaching through consciousness-raising approach includes two major phases (Schmidt, 1990; 1993). During the noticing phase, learners are exposed to native speakers' use of language through the discussion of the forms and grammar as well as the impacts of contextual factors. During this step learners notice the forms and functions of English (pragmalinguistics) and are aware of how native speakers evaluate social factors when using the language (sociopragmatics). Later, to gain more understating of pragmatic use of English interaction in the target language and the comparison of the intercultural pragmatic norms are required (Ishihara N., 2010). With all the efforts learners might acquire more understanding and insight of the targeted functions. Finally, they might employ what they have learnt as intake in real interaction (Schmidt, 1990; 1993). Through these activities learners will be able to apply the pragmatic norms in other settings when their English proficiency develops (Rose K. R., 1994).

Rose (2010) employed PCR in developing pragmatic competence of Japnanese studnets through the use of videos. The expert claims that PCR can be adopted in both ESL and EFL contexts as it aims to develop students' awareness of contextual different use of language and role of social factors in the variation. Similarly, Cruz (2015) put an attempt to use roleplay and control written activities to develop learners' pragmatic competence. Meanwhile, Martinez-Flor \& Soler (2007) compared the benefits of explicit and implicit teaching and found that both of them were beneficial in EFL classrooms.

\section{RESEARCH METHODOLOGY}

This part outlines the research method and research design employed in this study followed by the innovative course. In addition, the details about the participants, research tools, and data analysis are also presented.

\section{Research Method and Research Design}

This study employed a mixed-methods approach in which both the qualitative and quantitative methods were integrat- ed. Meanwhile, classroom action research was applied as a research design. It improve practitioners' own teaching and serve educational responsibilities (Young, Rapp, \& Murphy, n.d.) by systematically examining of a teacher's own pedagogies and exploring means to improve them (Jones \& Eric, 2004). It helps answer enquiries about how to improve student success in class (Cunningham, 2008) and encourages changes in practitioners' actions that results in professional growth (Burns, 1999). Even though, classroom action research fails to test hypotheses and lack generalizability (Yin, 2009), the major objective of this study is to investigate real problems in a certain research setting in order to depict the phenomenon regardless of testing hypotheses or providing the generalizable explanations for them. Besides, the results might be useful for any settings, which share similar circumstances to this study.

\section{The Innovative Class}

The innovative course includes twelve classes. The lessons were embedded in English for Communication course. The course was for third and fourth year students. Each session lasts for three hours. The Diagram 2 below illustrates the processes of the innovative class.

The diagram features three phases of the innovative classes, which include both deductive (teacher-provided pragmatic norms) and inductive instruction (learners' discovery of pragmatic norms) (Ishihara N., 2010). The first step was an explicit teaching of complaint and apology strategies. The three most favorable strategies employed by native speakers were presented. After that a set of complaint worksheets was distributed to assure observation, understanding, and awareness of native speakers' complaints in terms of the linguistic forms, functions, and politeness. By the end of phase 2, the participants were assigned to conduct an interview project with Thai and native speakers of English to promote participants' observation of expressions and awareness of the impact of contextual factors on strategy choices and politeness of Thai and English. The participants were required to request the interviewees to complete a ready-to-use Written 


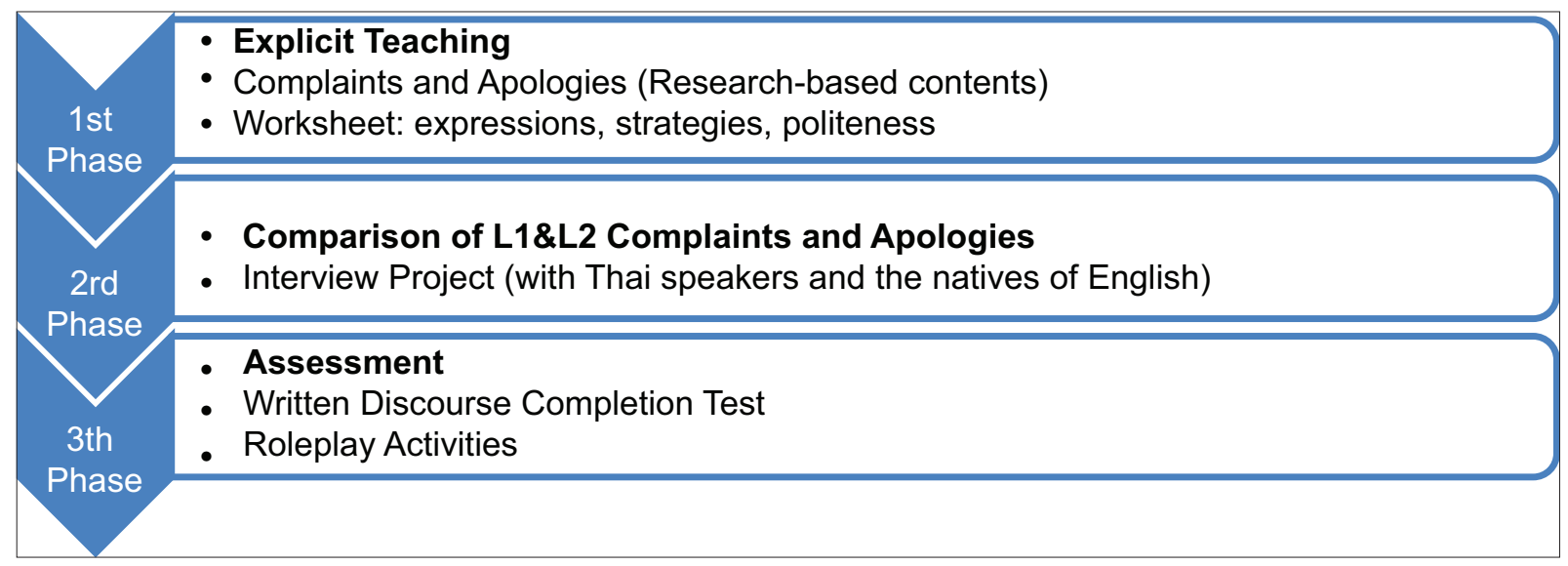

Diagram 2. The Innovative Class Sessions (Adapted from Ishihara (2010, pp. 113-115)

Discourse Completion Test form, which featured complaint and apology situations. After that they compare and contrast the Thai and native speakers' performances and presented the findings to the class. Finally, in the fourth session assessment through WDCTs and roleplay were conducted.

\section{The Participants}

Participants were forty-five third and fourth year engineering students at a Rajamangala University of Technology (RMUT). A purposive sampling technique was employed to obtain the participants.

\section{Data Sources}

A combination of both qualitative and quantitative methods was applied in this study. Both approaches could strengthen the validity and reliability of the answers to the research questions (Creswell \& Plano Clark, 2011). Firstly, two sets of written discourse completion test (WDCT) were applied in class as a pre-test and posttest to investigate participants' abilities to perform complaints and apologies. A WDCT is an open-ended questionnaire in which descriptions of communicative situations are provided, and students are required to completes the dialogue (Kasper \& Dahl, 1991; Gass \& Houck, 1999). Each speech act consisted of two communicative scenarios focusing on different power and social distance because they tend to be self-regulating and culturally sensitive variables (Brown \& Levinson, 1987; Cohen, 2010). The reliability of the research tools was maintained through the consultation with five researchers and a pilot testing. Another data source was a semi-structure interview with twelve participants to examine their perceptions of the innovative class. The guided questions were edited and revised by the five experts and was piloted tested.

\section{Data Analysis}

The analysis of WDCT data involved two phases. First, during the scoring phase three native speakers rated the data as they could also rely on their native norms in evaluating the answers. The rating criteria are based on Hudson (2001, p. 284) and Duan (2008, pp. 233-238). After that the scores were computed through paired-samples t-test to discover changes in the pre-test and posttest mean scores. In addition, the researcher employed Grounded Theory's color coding techniques (Strauss \& Corbin, 1998) to generate the findings on the students' perceptions of the PCR class.

\section{RESULTS AND DISCUSSION}

To serve the research objectives, two arenas of the results are presented below. They are an analysis of covariate and students' perception toward PCR classes.

\section{The Analysis of Covariate in the Pre-test and Posttest Mean Scores}

The mean scores from three native raters were compared through paired-samples t-test according to all the four criteria of pragmatic evaluation form Hudson (2001, p. 284) and Duan (2008, pp. 233-238). "Correct expression" and "Quality of information," aim to investigate pragmalinguistic abilities. First, "Correct expressions" refer to appropriate language forms with no grammatical mistakes, while "quality of information" associates with appropriateness of the amount of given information to serve a certain communicative purpose. The last two criteria focus on sociopragmatic competence. They are "strategy choices," which associates with the use of targeted communicative strategies and "politeness" which refers to suitable degree of directness of the strategies.

\section{Speech Act of Complaints}

The WDCT form features two complaint scenarios. In the first one a student was disappointed with an unexpected low grade. The two parties were close, but the student was lower in status $(-,+)$. Similarly, the second scenario aims at eliciting students' ability to reprimand a neighbor kid for smelly garbage. They were unfamiliar and students were higher in status $(+,-)$. The mean scores in the pre-test and posttest are compared below.

According to the Table 1, a significant difference between the mean scores in the pre-test and posttest of all criteria were found in both scenarios ( $p$ value $<.05$ ). Thus, there was de- 
velopment in students' use of English in transferring negative feelings to the higher status familiar lecturer and lower status unfamiliar neighbor. Obviously, the pre-test scores fell into scale 1, which equal to inappropriate and unacceptable language use both in terms of the forms and degree of politeness. However, the means scores rose to the scale of 2 or not very appropriate use of English, but acceptable.

\section{Speech Act of Apologies}

In this context, two apology situations were added in the WDCT form. In the first situation, students apologized to a lecturer for a broken coffee mug. The students were lower in status and familiar with the lecturer $(-,+)$. The other scenario centers around conveying the guilty feeling of a higher status students to a familiar young neighbor $(+,+)$. The comparison of the mean scores was as follows:

From the Table 2, It is obvious that the pre-test and posttest mean scores were rather high. From the mean scores of 2 referring to not very appropriate, but acceptable responses (almost 3 ) in the pre-test, they climbed up to 3 or moderately appropriate. Regarding the first scenario, the mean scores in the pre-test and posttest were significantly different in three areas; "correct expressions," "quality of information," and "strategy choices" ( $p$ value <.05) with no significant difference in "politeness." Similarly, no significant difference in

Table 1. Comparison of the pre-test and posttest scores in Complaint $1(-,+)$ and Complaint $2(+,-)$

\begin{tabular}{|c|c|c|c|c|c|c|c|}
\hline Scenarios & Criteria & Test & Mean & SD & df & $\mathbf{t}$ & Sig. \\
\hline \multirow[t]{8}{*}{1} & Correct Expressions & Pre-test & 1.20 & 1.057 & 44 & -6.612 & 0.000 \\
\hline & & Posttest & 2.49 & 1.014 & & & \\
\hline & Quality of Information & Pre-test & 1.13 & 1.079 & 44 & -6.612 & 0.000 \\
\hline & & Posttest & 2.56 & 0.967 & & & \\
\hline & Strategy Choices & Pre-test & 1.16 & 0.999 & 44 & -6.424 & 0.000 \\
\hline & & Posttest & 2.40 & 0.915 & & & \\
\hline & Politeness & Pre-test & 1.16 & 1.127 & 44 & -7.510 & 0.000 \\
\hline & & Posttest & 2.56 & 0.893 & & & \\
\hline \multirow[t]{8}{*}{2} & Correct Expressions & Pre-test & 1.67 & 1.279 & 44 & -4.776 & 0.000 \\
\hline & & Posttest & 2.51 & 0.661 & & & \\
\hline & Quality of Information & Pre-test & 1.58 & 1.252 & 44 & -4.776 & 0.000 \\
\hline & & Posttest & 2.33 & 0.739 & & & \\
\hline & Strategies Choices & Pre-test & 1.44 & 1.179 & 44 & -4.770 & 0.000 \\
\hline & & Posttest & 2.18 & 0.684 & & & \\
\hline & Politeness & Pre-test & 1.40 & 1.116 & 44 & -4.342 & 0.000 \\
\hline & & Posttest & 2.20 & 0.815 & & & \\
\hline
\end{tabular}

Table 2. Comparison of the pre-test and posttest scores in Apology $1(-,+)$ and Apology $2(+,+)$

\begin{tabular}{|c|c|c|c|c|c|c|c|}
\hline Scenarios & Groups & Test & Mean & SD & df & $\mathbf{t}$ & Sig. \\
\hline \multirow[t]{8}{*}{1} & Correct Expressions & Pre-test & 2.89 & 0.532 & 44 & -4720 & 0.000 \\
\hline & & Posttest & 3.38 & 0.650 & & & \\
\hline & Quality of Information & Pre-test & 2.87 & 0.548 & 44 & -5902 & 0.000 \\
\hline & & Posttest & 3.44 & 0.586 & & & \\
\hline & Strategy Choices & Pre-test & 2.80 & 0.548 & 44 & -4.811 & 0.000 \\
\hline & & Posttest & 3.40 & 0.618 & & & \\
\hline & Politeness & Pre-test & 3.33 & 0.739 & 44 & -1.461 & 0.151 \\
\hline & & Posttest & 3.56 & 0.586 & & & \\
\hline \multirow[t]{8}{*}{2} & Correct Expressions & Pre-test & 2.69 & 0.596 & 44 & -4.811 & 0.000 \\
\hline & & Posttest & 2.89 & 0.714 & & & \\
\hline & Quality of Information & Pre-test & 2.56 & 0.546 & 44 & -1.461 & 0.151 \\
\hline & & Posttest & 2.91 & 0.701 & & & \\
\hline & Strategy Choices & Pre-test & 2.51 & 0.549 & 44 & -4.304 & 0.000 \\
\hline & & Posttest & 2.96 & 0.737 & & & \\
\hline & Politeness & Pre-test & 3.18 & 0.442 & 44 & -0.650 & 0.519 \\
\hline & & Posttest & 3.24 & 0.609 & & & \\
\hline
\end{tabular}


the same criterion was found when students apologized to their neighbor as well as that of "quality of information" ( $p$ value $>.05$ ). However, the mean scores were significantly different in "correct expressions" and "strategy choices."

\section{Perceptions towards Learning through the Pragmatic Consciousness-Raising Classes}

This section reports findings from the interview data analysis with an attempt to answer the third research question concerning students' perceptions towards PCR, which featured explicit teaching of complaint and apology expressions and an interview project with native speakers of English. It can be concluded from the interviews that PCR class can be both beneficial and challenging.

Firstly, findings revealed that most participants perceived the significance of selecting language expressions used with different interactants considering three social factors; 1) social power, 2) social distance, and 3) level of severity (Cohen, 2010; Thomas, 1995). Next, the majority of participants were aware of the benefits of using indirect strategies. Thirdly, most participants perceived PCR to be favorable in boosting their understanding of how eye contact, facial expressions, and touching contributes to their verbal communication. Finally, the PCR class was motivating as it was seen as learner-friendly and interactive and the use of roleplay test seemed favorable for most students.

However, the PCR class was not flawless. Some participants were worried about using the strategies learned in class in real communication. Besides, they emphasized the requirement of including more grammar information in class. Lastly, the abilities to evaluate real communicative abilities through the roleplay tests were doubtful to some of the participants.

\section{DISCUSSION}

The findings through WDCTs confirm the teachability of pragmatics in EFL classrooms. They proved students' development in language use both in terms of the forms and abilities to maintain positive relationship with the interactants. The findings support previous studies which discovered the development of learners' abilities to use appropriate language through certain innovative approaches (Baghari \& Hamrang, 2013; Tchoutezo, 2010; Justin E., 2007; Rueda, 2004; Bardovi-Harlig, 2001; Kasper, 1997).

The prominent results from WDCTs support Schmidt's (2010; 1990; 1993) Noticing Hypothesis. The posttest scores showed significant changes in students' complaints and apologies. Moreover, through the interview most participants revealed their awareness of the influences of contextual factors on their use of English and perceived the favor of employing indirect strategies, which is line with the findings in Martínez-Flor \& Usó-Juan (2015).The study confirm students' noticing of pragmatic use of language, which seem to be congruent with Schmidt's (2010; 1990; 1993) Noticing Hypothesis. In this context, students consciously acquired pragmatic information by noticing the targeted expressions and understood the influences of contextual factors to some degrees until the inputs became intake (Schmidt, 2010; 1990; 1993).

In particular, the results confirm the benefits of explicit comparison of L1 and L2 complaints and apologies in class and through the interview project which follows the PCR approach (Rose K. R., 1999, p. 113). Most participants could differentiate native speakers' interaction from that of nonnative speakers in class and this resulted in more appropriate strategies used in the posttest. This confirms that exposing learners to pragmatic aspects of both L1 and L2 facilitates their generalization about appropriate language use (Rose K. R., 1999). Similarly, the results were in line with Kondo (2008, p. 172) who found the use of strategies which were more similar to that of native speakers and higher awareness of pragmatic aspects of learners resulted from participation in the PCR class.

However, the very low scores in "Correct expressions" and "Quality of information," especially in complaints, and the participants' concern about their grammatical abilities though the interview as well as the slight improvement showing through the posttest mean scores of all criteria emphasize critical consideration of implementing PCR in EFL class. Thus, the findings challenge the proposal of Rose (1994) about the outstanding advantages of PCR. It might be concluded that more attention to the development of linguistic competence is crucial. This is congruent with Ishihara \& Cohen (2010, p. 80). They maintain that poor grammatical abilities result in pragmatic failures; thus, teachers should include direct teaching of grammar abilities in class. This is more crucial in the foreign language environment where learners have limited opportunities to use English outside the classes. A comprehensive understanding of pragmatics and its importance in developing language proficiency are necessary in this context (LoCastro, 1945, p. xi).

\section{CONCLUSION}

In line with previous studies on the application of a Pragmatic Consciousness-Raising Approach in developing pragmatic competence, this study has showed that explicit discussion of forms, their functions, and the relationship with contextual factors, as well as the interview project with native speakers of English seemed to have positive influences on students' pragmatic use of English. However, the limitation of a narrow time gap between the pre-test and posttest is undeniable; thus, a delayed posttest might offer more reliable results regarding changes in students' pragmatic abilities. Additionally, it might be favorable to include more grammar-focused activities, especially in EFL contexts.

\section{ACKNOWLEDGEMENTS}

We would like to extend my heartfelt gratitude to Dr. Anamai Damnet and Asst.Prof.Dr. Kanjana Charttrakul for their invaluable comments to make this study well-rounded. We are very thankful to the National Research Council of Thailand (NRCT) for providing me with a graduate scholarship in conducting this research. 


\section{REFERENCES}

Association of Southeast Asian Nations. (2015). ASEAN ECONOMIC COMMUNITY BLUEPRINT. 1967: Association of Southeast Asian Nations.

Baghari, M., \& Hamrang, A. (2013). The Effect of Metapragmatic Instruction on the Interpretation and Use of Apology Speech Act of English as Foreign Language Learners (EFL) at Intermediate Level. International J. Soc.Sci. and Education, 4(3), 964-975.

Baker, W. (2011). From Cultural Awareness to Intercultural Awareness: Culture in ELT. ELT Journal (Online Version), 62-70.

Bardovi-Harlig, K. (2001). Evaluating the Empiracal Evidence: Ground for Instrcution in Pragmatics? In K. R. Rose, \& G. Kasper, Pragmatics in Language Teaching (Ed.) (pp. 13-32). Cambridge: Cambridge University Press.

Bergman, M. L., \& Kasper, G. (1993). Perception and Performance in Native and Nonnative Apology. In G. Kasper, \& S. Blum-Kulka, Interlanguage Pragmatics (pp. 82-108). Oxford Univeristy Press.

Brown, P., \& Levinson, S. C. (1987). Politeness. Cambridge: Cambridge University Press.

Burns, A. (1999). Collaborative Action Research for English Language Teachers. Cambridge: Cambridge University Press.

Center for Advanced Research on Language Acquisition. (2015, January 22). Descriptions of Speech Acts. Retrieved October 23, 2015, from carla.umn.edu: http:// www.carla.umn.edu/speechacts/descriptions.html

Cheng, D. (2013). Student Instructor Apologies: How Are They Preduced and Percieved? Ph.D. Thesis in Applied Linguistics: Northern Arizona University.

Choomtong, D. (2014). Preparing Thai Students' English for the ASEAN Economic Community: Some Pedagogy Implications and Trends. LEARN, 7(1), 45-57.

Cohen, A. D. (2010). Approaches to Assesing Pragmatic Ability. In N. Ishihara, \& A. D. Cohen, Teaching and Learning Pragmatics: Where Language and Culture Meet (pp. 264-285). UK: Pearson Education Limited.

Cohen, A. D. (2010). Coming to Terms with Pragmatics. In N. Ishihara, \& A. D. Cohen, Teaching and Learning Pragmatocs (pp. 3-17). United Kingdom: Pearson Education Limited.

Creswell, J. W., \& Plano Clark, V. L. (2011). Designing and Conducting Mixed Methods Research. USA: SAGE.

Cruz, M. P. (2015). Fostering EF/SL Learners' Meta-Pragmatic Awareness of Complaints and their Interactive Effects. Language Awareness, 123-137.

Cunningham, B. M. (2008). Using Action Research to Improve Learning and the Classroom Learning Environment. Issues in Acoounting Education, 1-30.

Dersiderio, A. M. (2011). Pedagogical Implications of Pragmatic Video Clips in an EFL Context with L1 Arabic Speakers. Master of Arts Thesis in Teaching English to Speakers of Other Languages: Michigan State University.
Dornyei, Z. (2013). Communicative Language Teaching in the Twenty-First Century: the Principled Communicative Approach. In J. Arnold, \& T. Murphy, Meaningful Action (Eds.) (pp. 161-171). Cambridge: Cambridge University Press.

Duan, L. (2008). The Effects of Explicit and Implicit Instruction on Appropriacy of English Refusal by Chinese EFL Students. Doctoral Thesis in English Language Studies: Suranaree University of Technology.

Ellis, R. (1992). Second Language Acquisition \& Language Pedagogy. Clevedon: Multilingual Matters.

Furukawa, N. (2006). Complaint Behaviors, Post Recovery Behaviors, and Effectiveness of Recovery Strategies: A omparative Study of American and Japanese Hotel Guests. Master of Arts Thesis: University of Hawai’ I.

Gass, S. M., \& Houck, N. (1999). Interlanguage Refusals: a Cross-cultural Study of Japanese English. New York: Mouton de Gruyter.

Ho, D. G., Henry, A., \& Alkaff, S. N. (2012). "You Don't Seem to Know How to Work": Malay and English Spoken Complaints in Brunie. Pragmatics, 3(22), 319-416.

Hudson, T. (2001). Indicators for Pragmatic Instruction: Some Quantitative Tools. In K. R. Rose, \& G. Kasper. USA: Cambrige University Press.

Ishihara, N. (2010). Class Observation and Teaching Demonstrations. In N. Ishihara, \& A. D. Cohen, Teaching and Learning Pragmatics: where language and culture meet (pp. 123-144). UK: Pearson Education Ltd.

Ishihara, N. (2010). Theories of Language Acquisition and the Teaching of Pragmatics. In N. Ishihara, \& A. D. Cohen, Teaching and Learning of Pragmatics: Where Language and Culture Meet (pp. 99-122). Cambridge: Cambridge Univerisity Press.

Ishihara, N., \& Cohen, A. D. (2010). Teaching and Learning Pragmatics: Where Language and Cultural Meet. UK: Pearson Education Limited.

Jones, D. K., \& Eric, R. R. (2004). Daily Classroom Improvement with Action Research. The Agricultural Education Magazine, 8-9.

Justin E., J. (2007). Insruction and Developing Second Language Pragmatic Competence: an Investigation into the Efficacy of Output. Dissertation: The Florida State University.

Kasper, G. (1997). Can Pragmatic Competence be Taught. Second Language Teaching and Cirriculum Center(Webpage).

Kasper, G., \& Dahl, M. (1991). Research Methods in Interlanguage Pragmatics. Studies in Second Language Acquisition, 215-247.

Kondo, S. (2008). Effects on Pragmatic Development Through Awareness-raising Instruction: Refusals by Japanese EFL Learners. In E. A. Soler, \& A. Martinez-Flor, Investigating Pragmatics in Foreign Language Learning, Teaching and Testing (pp. 153-176). Great Britain: Multilingual Matters.

Laopongharn, W., \& Sercombe, P. (2009). What relevence does intercutltural communcation have to language education in Thailand? ARECLS, 59-83. 
Lee, J. S. (1999). Analysis of Pragmatic Speech Style among Korean Learners of English: A Focus on Complaint-Apology Sequences. Ph.D Dissertation in Education: Standford University.

Leech, G. N. (1983). Principles of pragmatics. USA: Longman Limited.

LoCastro, V. (1945). An introduction to pragmatic: social action for language teachers. USA: The University of Michigan Press.

LoCastro, V. (1945). An Introduction to Pragmatic: Social Action for Language Teachers. USA: The University of Michigan Press.

LoCastro, V. (1990). Intercultural pragmatics: a Japanese-American Case Study. Dissertation: University of Lancaster.

Martinez-Flor, A., \& Soler, A. (2007). Developing pragmatic awareness of suggestions in teh EFL classroom: the focus on the instrutctional effects. RCLA-CJAL, 47-76.

Martínez-Flor, A., \& Usó-Juan, E. (2015). The Role of Instruction on EFL Learners' Use of Complaining-Apologising. Procedia - Social and Behavioral Sciences(212), 23-28.

McKay, S. L. (2002). Teaching English as an International Language: rethinking goals and approachs. Oxford: Oxford University Press.

Narita, R. (2009). The Effects of Pragmatic Conciousness- raising Activities on the Development of Pragmatic Awareness and Use of Hearsay Evidential Marker for Learners of Japanese as a Foreign Language. Dissertation: University of Hawai' $i$.

Ngowananchai, J. (2013). Nutural Occuring Conversation as an English Teaching Model in Thailand. European Scientific Journal, 397-408.

Panyawong-Ngam, L., Tangthong, N., \& Anunvrapong, P. (2015). A Model to Develop the English Proficiency of Engineering Students at Rajamangala University of Technology Krungthep, Bangkok, Thailand. Procedia - Social and Behavioral Sciences, 192, 77-82.

Ping, P. (2010). Making Request in Institutional E-mail Communication in Hongkong: An Interlanguage and Intercultural Pragmatic Approach. Dissertation: The Chinese University of Hongkong.

Pinya, S., \& Aksornjarung, P. (2010). Pragmatic competence in request: a case study with Thai English teachers. The $2^{\text {nd }}$ International Conference on Humanities and Social Sciences (pp. 1-15). Faculty of Liberal Arts: Prince of Songkla University.

Rose, K. R. (1994). Pragmatic Consciousness-Raising in an EFL Context. Pragmatics and Language Learning, 5(Monograph Series), 52-63.

Rose, K. R. (1999). Teachers and Students' Learning about Request in Hong Kong. In E. H. (Ed.), Culture in Second Languge Teahching and Learning. USA: Cambridge University Press.

Rudolph, D. (2001). Explicit instruction and JFL learner's use of interactional discourse markers. In K. R. Rose, \& G. Kasper, Pragmatics in Language Teaching (pp. 223-244). Cambridge: United Kingdom.
Rueda, L. Y. (2004). Effect of Pedagogical Intervention on the Development of Pragmatic Competence in Adult Learners of English as a Foreign Language. Dissertation: The University of Arizona.

Schmidt, R. (1990). The Role of Consciousness in Second Language Learning. Applied Linguistics, 129-158.

Schmidt, R. (1993). Awareness and Second Language Acquisition. Anuual Review of Applied Linguistics, 206-226.

Schmidt, R. (1993). Consciousness, learning, and interlanguage pragmatics. In G. Kasper, \& S. Blum-Kulka, Interlanguage Pragmatics (Eds) (pp. 21-42). New York: Oxford.

Schmidt, R. (2010). Attention, Awareness, and Individual Differences in Language Learning. Proceeding of CLaSIC 2010, 721-737.

Shea, H. K. (2003). Japanese Complaining in English: A Study of Interlanguage Pragmatics. Ph.D Thesis in Doctor of Education: Teachers College, Columbia University.

Soler, E. A., \& Matines-Flor, A. (2008). Pragmatic in Foreign Language Contexts. In E. A. Soler, \& A. Martinez-Flor, Investigating Pragmatics in Foreign Language Learnng, Teaching and Testing (pp. 3-21). Grate Britain: Cromwell Press Ltd.

Strauss, A., \& Corbin, J. (1998). Basics of Qualitative Research: Techniques and Procedures of Developing Grounded Theory. California: SAGE.

Sukimoto, N. (1995). A Japan-US Comparison of Apology Styles. Ph.D.Thesis in Speech Communication: Univeristy of Illinois at Urbana- Champaign.

Tchoutezo, E. (2010). Instruction and Development of Second Language Acquisition Pragmatic: an Investigation into Sociolinguistic Communicative Competence. Dissertation: Alliant Internatonal University.

The TOEIC ${ }^{\circledR}$ Tests - the Global Standard for Assessing English Proficiency for Business. (n.d.). Retrieved September 4, 2017, from www.ets.org: https:/www.ets.org/ toeic/succeed

Thomas, J. (1995). Meaning in Interaction: An Introduction to Pragmatics. London and New York: Longman.

Trosborg, A. (1995). Interlanguage Pragmatics: Requests Complaints and Apologies. Berlin, New York: Mouton Gruyter.

Wichien, S., \& Aksornjarung, P. (2011). Pragmatic Features in English Course Materials. English Studies in Various Contexts (pp. 1-17). Songkhla: Faculty of Liberal Arts, Prince of Songkla University.

Wongsothorn, A., Hirunburana, K., \& Chinnawong, S. (2006). English Language Teaching in Thailand Today. Asia Pacific Journal of Education, 107-116.

Yin, R. K. (2009). Case Study Research Design and Methods $\left(4^{\text {th }} e d\right)$. USA: Sage Ltd.

Young, M. R., Rapp, E., \& Murphy, J. W. (n.d.). Action Research: Enhancing Classroom Practice and Fulfilling Educational Respondsibility. Journal of Educational Pedagogies, 1-11.

Yule, G. (1996). Pragmatics. Oxford University Press 